\title{
Despre notele marginale din prima versiune românească integrală a Septuagintei (Ms. 45 de la Biblioteca Filialei din Cluj a Academiei Române)
}

\author{
Mădălina Ungureanu* \\ Departamentul de Cercetare Interdisciplinar - Domeniul Socio-Uman, Universitatea „Alexandru Ioan Cuza”, \\ Str. Lascăr Catargi 54, 700107 Iaşi, România
}

\author{
Despre articol \\ Istoric: \\ Primit 6 mai 2015 \\ Acceptat 29 iunie 2015 \\ Publicat 17 iulie 2015 \\ Cuvinte-cheie: \\ text biblic \\ traducere \\ vechea română literară \\ filologie \\ glose
}

\begin{abstract}
Rezumat
Ms. nr. 45 de la Biblioteca Filialei din Cluj a Academiei Române conține prima traducere românească integrală a Vechiului Testament în versiunea Septuagintei păstrată pînă astăzi, realizată de Nicolae Milescu Spătarul în a doua jumătate a secolului al XVII-lea. Istoria acestui text este descifrată doar parțial; se ştie că manuscrisul nu conține traducerea propriu-zisă, ci o revizie a ei. Identitatea revizorului, ca şi traseul urmat de text după această primă prelucrare, sînt încă disputate. Lucrarea de față își propune să studieze inventarul notelor marginale din două cărți biblice ale manuscrisului, Facerea și Iov, încercînd să stabilească o tipologie a lor; este un prim pas dintr-un demers necesar, studiul întregului inventar al notelor, care poate contribui la clarificarea aspectelor încă insuficient cunoscute ale istoriei textului.
\end{abstract}

\section{Preliminarii}

1.1. Despre prima traducere românească integrală a Vechiului Testament în versiunea Septuagintei (și, totodată, prima traducere a Septuagintei într-o limbă modernă, cf. Florescu, 2015, p. 74) s-a vorbit destul de mult, în timpul scurs de la descoperirea manuscrisului (Cândea, 1979, p. 108). Dată fiind importanța textului transpus, cercetătorii au fost interesaţi de diversele probleme ridicate de studiul său. Nimeni nu mai pune la îndoială astăzi identitatea traducătorului român (Nicolae Spătarul Milescu, cărturar de anvergură europeană, amintit, de altfel, într-una dintre prefețe, Cuvîntu înainte cătră cititori ${ }^{1}$ : „Iară Nicolaie, vrînd să aducă și el cartea aceasta den elinie la rumânie, nefiind altă dată scoasă la rumânie”"2); în schimb, alte chestiuni sînt, încă, disputate. Traducerea lui Milescu s-a păstrat în ms. 45 de la Biblioteca Filialei din Cluj-Napoca a Academiei Române. Numeroasele studii dedicate acestui manuscris (Cândea, 1979; Ursu, 2003; Andriescu, 1988, care expune și o viziune sintetică asupra discuțiilor) arată că el conține o revizie a traducerii lui Nicolae, copiată de Dumitru din Cîmpulung (care, de altfel, semnează la finalul cuprinsului, după obişnuitele versuri de închinare către mitropolit, astfel: „A sfințiii tale plecată slugă, Dumitru Dălgopolscom”). În acest punct apar divergențe între specialiști, referitoare la consistența reviziei (substanțială sau superficială) și la identitatea revizorilor ${ }^{3}$. În orice caz, este astăzi binecunoscut și acceptat de specialiști faptul că această revizie, păstrată în ms. 45, stă la baza textului veterotestamentar tipărit în B 1688.

*Adresă de corespondență: madandronic@gmail.com.

${ }^{1}$ Plasat la finalul traducerii, pe patru pagini nenumerotate, acest Cuvînt înainte are rolul unei prefețe, conținînd idei referitoare la importanța traducerii textului sacru și la istoricul acestei traduceri (unele preluate, așa cum arată Cândea, 1979, p. 112, cuvînt cu cuvînt din prefaţa ediției-sursă), la sursele folosite de traducător, la munca de revizie a traducerii și aspectele pe care le-a vizat aceasta. Cândea (1979) arată că predoslovia a preluat, probabil, multe dintre ideile prefeței pe care o va fi conținut protograful traducerii lui Milescu.

'2 Întrucît, în acest articol, ne-am folosit de transcrierea ms. 45, a ms. 4389 și a B 1688 efectuate în cadrul seriei Monumenta lingua Dacoromanorum. Biblia 1688 (MLD), am respectat normele de transcriere interpretativă stabilite în acest proiect (pentru care vezi Nota asupra ediției din volumele recente ale seriei).

${ }^{3}$ În această din urmă problemă, au fost propuse două soluții. Una dintre ele îi aparține lui N.A. Ursu, care îl propune pe Dosoftei, mitropolitul Moldovei, drept autor al reviziei (o revizie, spune cercetătorul, substanțială, atît de radicală încît mitro- 
Mădălina Ungureanu

În ciuda studiilor amintite, numeroase probleme legate de textul conținut în ms. 45 au rămas nerezolvate; una dintre cauzele acestui lucru o constituie, probabil, faptul că textul manuscrisului nu este încă disponibil integral, într-o ediție filologicắ . În afară de identitatea primului revizor al traducerii lui Nicolae, am mai aminti aici chestiunea surselor traducerii şi ale reviziei; raportul dintre traducere și revizie (cu alte cuvinte, ce anume îi aparține lui Milescu și ce traducătorului); raportul textului cu B 1688 (ce și cît este preluat, în Biblie, din ms. 45 și ce alte surse folosește Biblia lui Șerban în Vechiul Testament); raportul cu cealaltă traducere integrală cunoscută din epocă a Vechiului Testament, conținută în ms. rom. 4389 B.A.R. şi atribuită lui Daniil Panoneanul (Ursu, 2003, p. 29-30).

În ceea ce privește originalul traducerii lui Milescu, Cuvîntul înainte cătră cititori menționează că sursa principală ar fi , un izvod carele-i mai ales decît toate altele, tipărit în Frangofort și ales foarte bine pre limba elinească, și dedesupt cu multe arătări și cuvinte puse cum le-au tălmăcit alții”, identificat drept Biblia tipărită la Frankfurt în 1597 (Cândea, 1979, p. 112), la care s-ar adăuga, după mărturisirea predosloviei, alte izvoare latinești și slavonești (Biblia Ostrog, 1581). De asemenea, aceeași prefață atribuită revizorului arată sursa după care a lucrat el însuşi: „Iară şi noi pre lîngă izvodul lui Necolaie am mai alăturat și alte izvoade grecești, pren care izvoade fost-au unul carele au fost tipărit la Englitera” (Sept. Londra, 1653), la care se adaugă Biblia Ostrog, din care a luat trimiterile biblice marginale („şi încă am pus şi mărturiile cuvintelor prorociilor den cea slovenească, tot pre margine, neavîndu-le cêle grecești”), precum și modalitatea în care a alternat sursele („Și așa am venit cu acela izvod pînă la Paralipomenon dentîi, și apoi aflînd și noi izvod grecescu, altul de cêle den Frangofort, dupre care au scris și Necolaie, am urmat aceluia”). Arătînd că textele celor două surse grecești nu coincid („ci și acesta [ediția de la Londra, n.n.] nu să potriviia cu cel de la Frangofort, pentru căci pren bogate locuri adăogea și pren bogate locuri lipsiia, nu veniia cu cestalalt"), revizorul descrie și modul în care a rezolvat problemele ridicate de aceste diferențe textuale ale surselor: „pentru acêea lipsele nu s-au socotit, iar adaosele s-au pus precum vom face dosluşirea mai jos cu însemnări”. Așadar, diferențele dintre sursele grecești, spune revizorul, adică Sept. Frankfurt, pe care o traduce Milescu, și Sept. Londra, pe care o folosește el însuși pînă la 2Par, lipsindu-i izvorul principal al lui Milescu, au fost indicate în text, într-o manieră pe care o explică el însuși și pe care o vom indica mai jos.

Ne vom îndrepta atenția, în lucrarea de față, asupra notelor marginale din ms. 45. Dat fiind materialul imens pe care îl pune la dispoziție manuscrisul (ms. 45 are 906 pagini, fiecare pagină cu două coloane ${ }^{5}$ ), ne-am oprit asupra a două cărți biblice: Facerea și Iov. În alegerea lor, am avut în vedere ceea ce spune revizorul în prefața sa: a. că Milescu, după chiar mărturisirea lui, ar fi intenționat să consemneze și variantele oferite de surse, inclusiv de aparatul critic al ediției de la Frankfurt, dar, de fapt, a reuşit să facă acest lucru numai la prima carte a Pentateubului (,și au scris și cêle precum să afă la letenie și cêle precum să află la slovenie și însemnările și tălmăcirile cêle ce să află mai jos la izvodul acel grecescu, zice că le-au pus tot cu însemnări pre de margine, dară n-au pus nice unele de acêstea la izvodul lui; că au început să facă și acêstea la capul dentîi, la Bitie, dar mai d-apoi, pentru neașezămîntul vremilor, s-au lăsat și n-au făcut nice unele de acêstea"); b. că el însuși, revizorul, a folosit, pînă la 2Par, alt izvor decît cel de la Frankfurt, iar apoi, procurîndu-și-l pe acesta, l-a folosit exclusiv, în a doua parte a textului. Am ales, aşadar, cîte o carte ilustrativă pentru cele două părți astfel delimitate din perspectiva izvoarelor utilizate, cu scopul de a vedea dacă această alternanță a surselor se reflectă în notele marginale și, mai mult decît atît, care este rolul acestor însemnări.

politul poate fi socotit „coautor” al traducerii), aducînd argumente de ordin lingvistic care plasează limba revizorului în aria nordică a teritoriului românesc și argumente de ordin lexical și morfologic care ar constitui „mărci” ale scrisului mitropolitului. Cealaltă ipoteză îi consideră drept autorii reviziei traducerii lui Milescu pe „dascălii locului”, cărturari munteni care, acționînd la îndemnul mitropolitului Teodosie al Țării Românești, pregătesc textul pentru tipar.

${ }^{4}$ Textul manuscrisului a fost publicat începînd cu 1988 și pînă în prezent, parțial, în volumele din seria MLD, la Editura Universității „Alexandru Ioan Cuza” din Iași. O ediție filologică a ms. 45 este în pregătire, în cadrul unui proiect condus de Eugen Munteanu.

${ }^{5}$ Vezi descrierea manuscrisului în Nota asupra ediției din volumele recente ale MLD. 
1.2 Problema notelor marginale din ms. în discuție a fost abordată de Ursu (2003), în încercarea de a argumenta paternitatea lui Dosoftei asupra reviziei traducerii lui Milescu. Astfel, autorul este interesat de aspectul formal, lingvistic, al notelor, mai precis, de trăsăturile fonetice, morfologice și lexicale care ar putea releva similitudini cu limba textelor lui Dosoftei. O încercare de sistematizare a gloselor din ms. 45 îi aparține Anei-Maria Gînsac (Gînsac, 2013). Autoarea încearcă o tipologizare, identificînd: 1. Note privind morfologia textului și 2. Note lexicale (2.1. explicații ale terminologiei folosite; 2.2. explicații ale calcurilor din text; 2.3 . sinonime care rezolvă diferențele de ordin diatopic dintre traducere și revizie; 2.4 . sinonime care oferă variante de traducere sau sînt mai adecvate sensului din original).

Dacă avem în vedere definirea glosei ca „o formă perfecționată de împlinire a textului în limba țintă. Forme și structuri proprii acesteia se concentrează asupra cîte unui conținut din limba sursă în scopul redării deslușite a respectivului conținut...” (Gafton, 2005, p. 44), trebuie să facem distincție între notele marginale și glose, în sensul că doar o parte a notelor sînt glose. Anticipînd, vom spune că nu toate notele marginale (ba chiar numai o parte destul de restrînsă a lor) din ms. 45 rezultă din contactul dintre două (sau mai multe) sisteme lingvistice diferite și din necesitatea ajustărilor (lingvistice). Unele note rezultă din confruntarea mai multor izvoare şi din nevoia de a oferi receptorului un text complet; altele sînt preluate chiar din izvoare și au rolul de a orienta în interiorul sistemului biblic. De asemenea, dacă glosele nu apar ca urmare a unui sistem prestabilit (Gafton, 2005, p. 198), notele de care ne ocupăm au caracter sistematic, demonstrat de semnele grafice diferite folosite consecvent pentru fiecare categorie și de expunerea acestui sistem în prefaţă.

Literatura secundară referitoare la glosele din textele vechi românești-perioada veche și premodernă—este bogată (vezi, pentru o imagine de ansamblu, Gafton, 2012, p. 329, nota 282; Soare, 2015, p. 3, nota 4; autorii menționează contribuțiile lui D. Șesan, G. Țepelea, N. A. Ursu, Mario Roques), întrucît materialul în sine este bogat și variat. Discuția cea mai amplă pe marginea acestui subiect se găsește la Gafton, 2005, p. 44-46 și 196-268. Văzute ca o componentă a actului traducerii, ca rezultat al conștientizării, de către traducător, a dificultății actului de traducere, glosele sînt clasificate în: explicative, completive, orientative (Gafton, 2005, p. 44-46). Mai departe, analizînd un număr considerabil de glose, excerptate din texte de tipuri diferite, din secolele al XVI-lea - al XVII-lea, autorul stabilește și alte categorii, avînd drept criteriu rolul acestor notații în text, nevoia care le-a generat; glosele aveau multiple funcții, cea mai importantă fiind aceea de a armoniza trăsăturile morfosintactice și lexico-semantice ale celor două sisteme lingvistice puse în contact prin actul traducerii, prin explicaţii, completări, traduceri ale unor xenisme, detalieri pe marginea unor referenți străini de spațiul românesc, indicații adresate cititorului. Nu toate aceste glose sînt marginale; unele dintre ele sînt integrate în text în formă apozitivă, introduse prin adverbul adecă. Glosele constituie un „discurs paralel” (Gafton, 2005, p. 259, 267), care tinde să rezolve neajunsurile traducerii literale și contribuie la formarea aspectului literar al limbii române.

Ne vom ocupa, în cele ce urmează, de inventarul notelor marginale din cele două cărți biblice, aşa cum apar în ms. 45, urmărind un studiu cantitativ şi calitativ. Vom încerca să determinăm tipologia notelor, funcția lor textuală, indicațiile pe care le oferă despre legătura dintre textul propriu-zis, cel conținut în ms. 45 și tradiția textuală (nu doar cea românească) a Bibliei ${ }^{6}$.

1.3. Tot Cuvîntul înainte cătră cititori oferă o „decodare” a semnelor folosite pentru marcarea inserției textuale a diverselor notații din interiorul textului sau marginale (într-o secțiune specială, intitulată „Doslușirea cărții aceștiia cum vei putea să o înțelegi, citindu-o mai pre iușor"). Astfel, un semn special ( “u, numit „sile”) indică sau glose sinonimice, sau lecțiuni diferite în surse: „Iar unde vei vedea acesta $u-7$

\footnotetext{
${ }^{6}$ Despre Biblie ca hipertext, vezi Munteanu, 2011, p. 16.

${ }^{7}$ Notat cu roșu în text și reluat marginal.
} 
asupra unui cuvînt, cîte vor fi înlăuntru și afară silele acêstea, acela sau e cuvînt de îndoire, de zice sau aşa, sau aşa, sau el s-au aflat într-un izvod într-un chip, și într-alt izvod într-alt chip şi fără bănuială sînt aşa.” Un semn (o „silă”) roșu cu un punct dedesubt marchează o omisiune în text: „acoleá iaste cuvînt sărit și s-au îndreptat afară.” Pentru marcarea trimiterilor biblice se folosesc două linii paralele: „să știi că de acoleá să încêpe cuvîntul mărturiei ce însemnează afară, și precum însemnează capetile, așa le vei afla”, iar pentru trimiterile intratextuale se folosesc indicațiile „sus” și „jos”. În sfîrșit, alte tipuri de notaţii marginale menționate aici sînt trimiterile la pasaje cu o interpretare mesianică, marcate printr-un desen special, o mînă roșie cu indexul îndreptat spre textul respectiv. Scopul acestui sistem de note, spune autorul prefeței, este dezambiguizarea, facilitarea orientării cititorului în text: „Așa luînd bine aminte nu te vei învălui, ci toate pre tocmêle le vei afla.".

După cum se poate observa, există un sistem coerent de marcare a intervențiilor asupra textului, a corecturilor survenite din confruntarea traducerii lui Milescu cu originalul, a adăugirilor făcute prin compararea cu celălalt izvor grecesc, a sistemului de relații din interiorul textului biblic însuși. Aceste notații nu sînt proprii doar acestui text, el este întîlnit și în alte manuscrise din epocă. Vom vedea, însă, că istoria textului de după redactarea prefeței a dispus apariția și a altor tipuri de note decît cele enumerate aici.

\section{Inventarul notelor marginale}

Dată fiind existența unui hiatus (menționat mai sus, \$1.1.) în ceea ce privește consultarea surselor grecești în procesul de revizie, ne-am oprit asupra notelor marginale din două cărți biblice: Facerea și Iov. Le vom discuta pe rînd, încercînd o tipologizare a notelor, pentru a urmări dacă cele două cărți cuprind tipuri similare de note marginale.

\subsection{Notele marginale din Facerea}

În manuscris, cartea Facerii este cuprinsă între paginile 1-51; pe margine apar aproximativ 300 de notații de diverse tipuri.

\subsubsection{Note care trimit la sistemul biblic ${ }^{9}$}

Cele mai multe dintre acestea sînt trimiteri biblice, la pasaje din alte cărți biblice (de tipul: Iosia 24) sau în interiorul aceleiași cărți (marcate, așa cum este indicat și în prefață, prin termenii jos și sus: jos 31 - la 28, 18; sus 26 - la 27, 46 etc.). O notă poate cuprinde mai multe trimiteri biblice sau trimiteri biblice de ambele tipuri (Mth. 19; 1 Cori. 11; Colas. 3; gios 8 și 9, la 1, 27). Titlurile cărților biblice sînt prescurtate. Numărul lor este însemnat: 122 de astfel de note în cartea Facerii. După cum se afirmă în prefaţă, acestea au fost preluate din izvorul slovenesc (Biblia Ostrog): „,̦i încă am pus și mărturiile cuvintelor prorociilor den cea slovenească, tot pre margine, neavîndu-le cêle grecești”.

În aceeaşi categorie, a notelor care indică o relaţie din interiorul sistemului biblic, integrăm marcarea pasajelor pasibile de o interpretare mesianică, indicate, așa cum se spune în prefață, printr-un desen reprezentînd o mînă cu indexul îndreptat spre pasajul respectiv. Sînt 20 de astfel de note marginale în această carte.

Tot pe margine, dar fără un marcaj special, apar indicații biblice (scurte comentarii rezumativ-orientative $)^{10}$. Cele mai multe sînt scrise cu roșu, de aceeași mînă: 65 de astfel de comentarii (în mod curios, începînd cu capitolul al 19-lea, înainte de care nu se găsesc astfel de notații). Multe dintre aceste comentarii au caracter indicativ, rol marcat prin utilizarea adverbului aici: Aici au adăpat pre Lot fêtele lui (19, 32);

\footnotetext{
${ }^{8}$ În afară de notațiile marginale, se mai face referire la notații care indică modificări de topică (prin plasarea slovelor cu valoare cifrică B, $\mathbf{\Delta}, \boldsymbol{\Gamma}$ deasupra secvențelor destinate permutării), marcarea începutului și a finalului versetelor, secvențe sau termeni aflați doar în unele dintre izvoare (fără ca absența acestora din altele să impieteze asupra sensului), cu o indicare specială, cu roșu, a celor care se află numai în izvorul de la Londra.

${ }^{9}$ Prin sistem biblic înțelegem aici ansamblul textelor biblice din diversele culturi, împreună cu tradiția biblică universală și cu cea caracteristică fiecărei culturi în parte; cf. fractalul Bibliei (Florescu, 2015, p. 57).

${ }^{10}$ Aceste comentarii nu se găsesc în sursele declarate ale traducerii.
} 
Aici puse Avraam giurămîntul cu Aviméleh (21,24); Aici au făcut Isaacjurămîntu cu Aviméleh (26, 26); Aici să blagoslovêște Isav (27, 39); Aici au vădzut Iacov tabăra lui Dumnedzău (32, 1) etc. Altele au caracter rezumativ, notația indicînd o acțiune: Sluji Iacov pentru Rabil 7 ani (29, 18); Să dăosăbi Isav de Iacov (36, 6); Aflară сира $(44,12)$ sau un obiect care constituie centrul de greutate al pasajului: Movila Mărturiei $(31,46)$; Daruri ce au trimis Iacov lui Isav $(32,13)$; impreunarea fraților $(33,3)$. Cele mai multe folosesc persoana a III-a, dar o dată se folosește și persoana a II-a, comentariul fiind o preluare directă a unei secvențe din verset: Luîndu pre tatăl vostru, veniți $(45,18)$. Din punctul de vedere al construcției, cele mai multe au realizare propozițională, simplă: Prăvăli piatra $(29,10)$; Plînse Iosif $(43,30)$ sau complexă: Poftiră oamenii a să obrăzui $(34,20)$; mai rar, ele sînt exprimate printr-o frază: Să arătă Dumnedzău lui Iacov și să pogorî cu însul la Eghiptu $(46,3)$ și doar uneori indicația este exprimată printr-un grup nominal: Visul lui Iosif (37, 4); Argintul și cupa $(44,2)$. De cîteva ori este indicată continuitatea între comentarii, conjuncția copulativă şi arătînd că acestea fac parte din aceeași unitate sintactică: Și ochi muiêrea stăpînului Pentefri pre Iosif $(39,7)$ și-l trase de contoș $(39,12)$; Puse pre Iosif domnu Eghiptului $(41,41)$ și-i dêde lui Iosif pre Asineth (41, 45); Și lipsi argintul din Eghiptu (47, 15) și dobitocul $(47,17)$.

Astfel de indicații, atît de numeroase în Facerea, sînt din ce în ce mai puține în cărțile următoare ale Pentateubului, iar începînd cu Deuteronomul lipsesc.

Un comentariu marginal amplu, scris cu negru și inserat textual printr-o steluță roșie, se găsește la 3, 23. Versetul sună astfel: „Și-l scoase pre însul Domnul Dumnedzău den grădina desfătăciunei ca să lucrêdze pămîntul dentru care s-au luat.” Nota marginală comentează: „Cel de viață lemn era lucrare de dare de viață ce să zice celor destoinici vieții și morții nesupuși, cu o dată prin hrană; ci Adam, după ce a gustat din lemn, fu supus morții și vieții nedăstoinic, precum și Iov mărturisêște grăind: «Chiemaiu moartea în loc de tată », pentru aceasta Dumnezeu grăiêște ca nu cîndva să tinză mîna și să ia din lemnul vieții, și va fi viu în vêci; că era contenită lucrarea cea de dare de viață carele întru cêle dentîiu era în om și striin de fericita viață și de hrană, precum Dumnezeu cătră dînsul grăiêște: «Întru griji să mănînci în toate zilele vieții tale.»”

Cîteva observații pe marginea acestui comentariu. Este scris de aceeași mînă, dar cerneala nu are aceeași culoare ca cea cu care este scris textul biblic (este ceva mai estompată), ceea ce ar însemna că el a fost adăugat într-o etapă ulterioară; autorul său poate fi revizorul, iar copistul l-a înregistrat, aşa cum face cu toate celelalte observații. Comentariul conține două citate biblice, unul din Iov $(17,14)$ și unul din Facere $(3,17)$; nici unul dintre ele nu reproduce textul din ms. 45, nici măcar pe cel din Fac, 3, $17^{11}$, aflat pe aceeași pagină cu comentariul, ceea ce arată că autorul comentariului citează, așa cum se întîmplă adesea în epocă, din memorie. Comentariul are rolul de a situa versetul în context și de a orienta lectura, dezvăluind sensurile pasajului.

Astfel de comentarii, marcate prin steluță, mai apar în textul manuscrisului de două ori: Jud, 2, 1 („Și să sui îngerul Domnului de la Galgála la locul plîngerii și la Vethil și la casa lui Israil și dzise cătră ei”): „Jid[ovii] dzic să fie Finees” (primele două cuvinte cu roșu, celelalte cu negru, probabil scăpare a copistului care nu a integrat însemnarea în categoria corectă de la început; steluța este deasupra sintagmei „îngerul Domnului”, comentariul făcînd trimitere la identificarea, existentă în unele versiuni ebraice, dintre înger şi Phineas, unul dintre marii preoți menționați în Exod); $1 R g, 14,14$ („Și să făcu rana cea dentîi, carea au lovit Ionathan și cela ce rădica ciniile lui, ca vro 20 de oameni, cu lovituri și cu aruncări de pietri și cu bulgări de ai cîmpului): „Alții dzic cît ară putea ara 2 boi într-o dzi” (prin pronumele nehotărît alții, revizorul desemnează versiunile din afara tradiţiei Septuagintei, cf. Vulg. Anvers: „quam par boum in die arare consuevit” și mai ales Biblia Ostrog: „юже два волы днь изорати”; în afară de steluță, comentariul este marcat, suplimentar, prin mai multe „sile” roșii pe ultima parte a versetului, fiindcă nu este doar un comentariu, ci înregistrează o altă versiune a textului biblic, operaţie astfel marcată în text, în mod obișnuit).

\footnotetext{
${ }^{11}$ În ms. 45, cele două versete sună astfel: „Moartea am chemat tată să-mi fie” (Iov, 17, 14); „întru scîrbe vei mînca pre însul toate dzilele vieții tale” (Fac, 3, 17).
} 


\subsubsection{Note marginale care privesc relația textului cu sursele}

Mare parte a notelor marginale se referă la aspectele amintite în prefață, consemnînd apelul la diverse surse ale traducerii. Cele mai multe note rezultă din implicarea celor două surse grecești menționate: ediția de la Frankfurt (1597), sursa principală a traducătorului, și ediția de la Londra (1653), sursa principală a revizorului pînă la 2 Par. Rezultă, din confruntarea acestor două texte, pe de o parte, și din confruntarea dintre traducere și sursă, pe de altă parte, notații diverse, care pot fi încadrate în următoarele categorii:

a. note marginale care consemnează o omisiune a traducătorului sau a copistului, aducînd completarea necesară (vizează secvențe care se regăsesc în ambele surse grecești). Cele mai multe sînt scrise de aceeaşi mînă, marcate cu un semn special (o silă cu un punct dedesubt, notate cu roșu): 6, 12 „Și vădzu

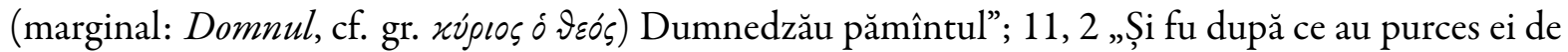
la răsărit, aflară cîmpu în locul lui Senaar și lăcuiră (marginal: acolo, cf. gr. $\varkappa \alpha \tau \omega ́ \varkappa \eta \sigma \alpha \nu ~ \varepsilon ́ \varkappa \varepsilon \tilde{l}) ; 27,13$ „S,i-i dzise lui maica sa: Pre mine blăstămul (marginal: tău, cf. gr. $\dot{\eta} \varkappa \alpha \tau \alpha ́ \rho \alpha \sigma o v)$, fiiul mieu”; 32, 28 „ce numai Israil să fie (marginal: numele, probabil omisiune a copistului) tău, căci te-ai întărit cu Dum-

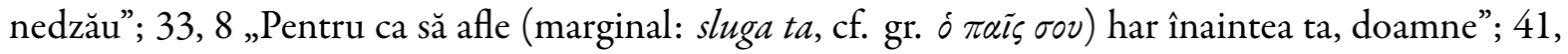
34 „Și facă faraon și tocmască mai mari preste locuri pre pămîntu și să trimiță toate pîinele (marginal:

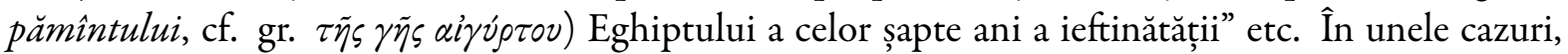
după cum se poate observa, omisiunea poate fi pusă fără discuție pe seama copistului (lipsește din text o componentă obligatorie, presupusă de context); în altele, se poate presupune că omisiunea este sau a copistului, care a revenit asupra textului ulterior și a observat-o, sau a traducătorului.

În trei situații, omisiunea este corectată printr-o notă marginală de altă mînă și marcată printr-o silă fără punct: 2,8 „Și răsădi Dumnedzău grădină în Edem, cătră răsărit, și puse (marginal: acolo, cf. gr. $\dot{x} x \tilde{\imath})$ pre om”; 3, 24 „Și-l scoasă afară pre Adam și-l lăcui pre însul în preajma grădinei (marginal:

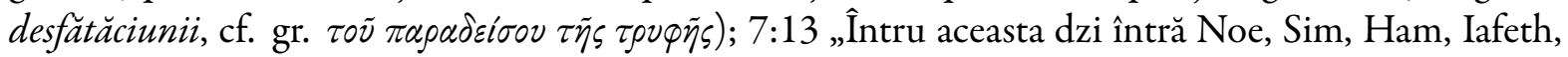

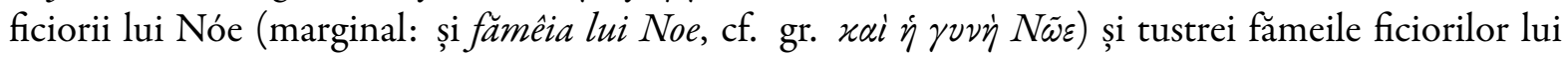
cu însul în săcriiu”. Asupra identității acestui scriptor se poate specula. Să fie unul dintre revizorii bucureșteni care au diortosit textul în vederea tipăririi? Intervențiile de acest tip sînt prea rare pentru a autoriza o astfel de supoziție.

b. note marginale care înregistrează secvențe în plus în Sept. Londra față de Sept. Frankfurt. După cum se anunță în prefață, revizia consemnează numai ceea ce ediția din 1653 are în plus față de cea mai veche (,acesta [izvorul de la Englitera] nu să potriviia cu cel de la Frangofort, pentru căci pren bogate locuri adăogea și pren bogate locuri lipsiia, nu veniia cu cestalalt; pentru acêea lipsele nu s-au socotit, iar adaosele s-au pus precum vom face doslușirea mai jos cu însemnări”): 3,8 „Și să ascunseră Adam și muiêrea lui de fața Domnului Dumnedzău în mijlocul (marginal: lemnului, cf. Sept. Londra: $\dot{\varepsilon} v$

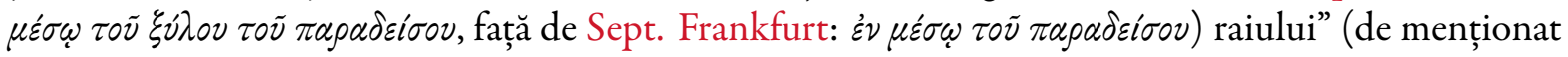
că aparatul critic din subsolul ediției de la Frankfurt înregistrează adaosul); 6, 3 „Să nu rămîie duhul

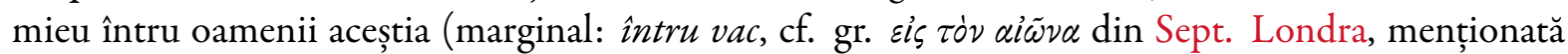
de Sept. Frankfurt în subsol) pentru că trupuri sîntu ei”; 7, 14 „Și toate jigăniile după fêliu-și și toate dobitoacele după fêliu-și și tot tîrîitoriul ce să clătêște pre pămîntu după fêliu-și și toată pasărea

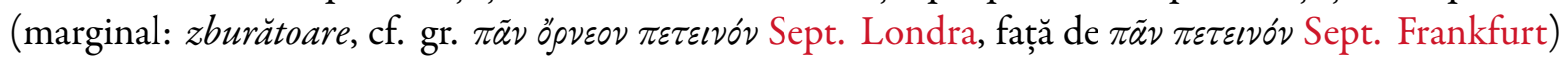

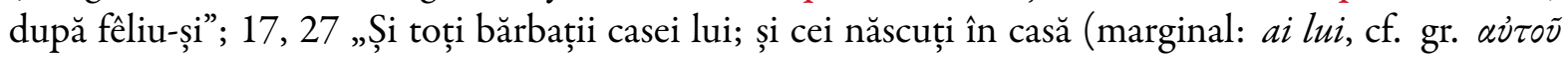
Sept. Londra, menționat în aparatul critic al Sept. Frankfurt) și cei cumpărați pre argintu dentru alte

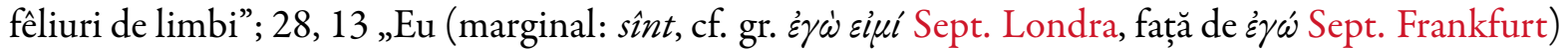
Dumnedzăul lui Avráam, tătîne-tău”.

c. note marginale care înregistrează diferențe între sursele grecești, semnalate prin sile. Este un loc comun faptul că nu există un textus receptus al Septuagintei, între diversele sale ediții existînd diferențe, în funcție de lecțiunile din manuscrisele care au stat la baza lor; de aceea, studiul relației dintre o traducere modernă a Septuagintei și textul grecesc trebuie să aibă în vedere nu orice ediție modernă a acestuia, ci chiar chiar textul-sursă care a stat la baza traducerii, altfel comparația duce la concluzii 
false $^{12}$. Acest lucru era conștientizat de traducătorii din vechime, inclusiv de cei implicați în realizarea primei versiuni românești a Septuagintei, întîi fiindcă revizorul reclamă necesitatea de a avea la dispoziție ediția de la Frankfurt, cea utilizată de Milescu, pentru o comparație judicioasă (folosește ediția de la Londra numai fiindcă nu a găsit izvorul de la Frankfurt, iar în momentul în care îl găsește, continuă revizia după acesta), apoi fiindcă el nu înlocuiește în text, ci înregistrează diferențele marginal. Vom exemplifica. În v. 10, 28 „Și Avimeil, și Sovef” (marginal: Sava), nota consemnează forma diferită a numelui propriu din Sept. Londra ( $\left.\sum \alpha \beta a ́\right)$ față de Sept. Frankfurt ( $\left.\sigma \omega \beta \varepsilon v ́\right)$. Lecțiuni diferite ale surselor grecești se constată și în v. 11,8 „S,ii-i răşchiră (marginal: sămănă) de acoló Domnul preste fața a tot pămîntul și potoliră a face cetaatea și turnul"; în Sept. Frankfurt este folosit verbul $\sigma \pi \varepsilon i \rho \omega$ 'to sow seeds; to plant; to scatter abroad, disperse' (Muraoka; cf. și Liddell-Scott: 'scatter like seed; spread abroad, extend'), în timp ce Sept. Londra are dı $\iota \sigma \pi \varepsilon i \rho \omega$ 'to disperse, scatter' (Muraoka). Lecțiunile din textele grecești sînt diferite; totuși, aici nota pare mai degrabă că precizează sensul, limitîndu-l în sensul lecțiunii din Frankfurt; limitarea este sau o eroare de interpretare, sau o alegere dictată de tradiție (pentru rolul tradiției în traducerea textului biblic, vezi Florescu, 2015, capitolul Pentru o reevaluare a literalismului). в 1688 are, în acest context, a răsipi, verb cu care revizorii bucureșteni înlocuiesc, într-o manieră inconstantă, forma dialectală moldovenească a răşchira pe care o găsesc în textul ms. 45 (Arvinte, 1988, p. 54-55). În v. 30, 13 „Și să duse Ruvim, în dzilele sêcerii de grîu, şi află miêre de mătrăgună (marginal, marcată în text printr-o silă deasupra ultimei slove a cuvîntului, este corectura $e$, propunînd lecțiunea mătrăgune) și le aduse la Lia, maica lui”, nota marginală indică diferența dintre sursele grecești, care conțin același termen ( $\left.\mu \alpha \nu \delta \rho \alpha o^{\prime} \rho \alpha \varsigma\right)$, la singular în Sept. Frankfurt, dar la plural în Sept. Londra. În v. 36, 13 „Și aceștia-s ficiorii lui Raguil: Nahoth, Zare, Some, Moze. Acesta (marginal: aceştia, corectînd o eroare a traducătorului) au fostu ficiorii Vasamáth (marginal, marcată printr-o silă roșie inversă deasupra celei de-a doua vocale a cuvîntului, corectura: $e$, indicînd lecțiunea Vasemath), fiii lui Isav", este posibil ca forma Vasamath să se datoreze unei erori grafice, fiindcă forma

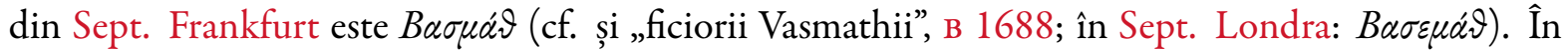
43, 7 „Au știut-am să (marginal: $c \breve{a}$ ) ne va dzice noao”, nota marginală nu conține, cum s-ar putea crede, o corectură a revizorului, ci înregistrează lecțiunea diferită din Sept. Londra: ó $\tau \iota$, față de Sept. Frankfurt: $\varepsilon i$.

Însă nu toate diferențele dintre sursele grecești sînt semnalate. De exemplu, versetul 30, 16: „Și veni Iacov de la țarină sara și întră (marginal: veni) Lia în timpinarea lui și dzise”. În poziția semnalată

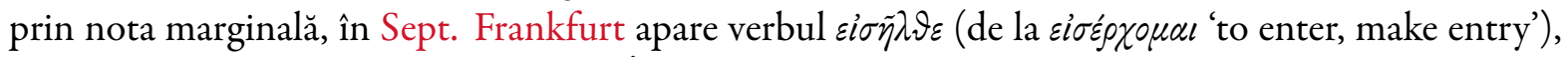

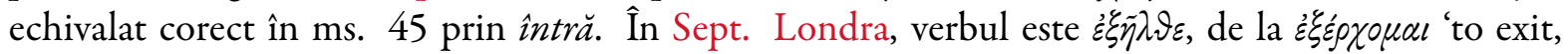
depart from a confined place'; 'to emerge, appear' (Muraoka, care indică drept antonim al lui tocmai verbul prezent în Sept. Frankfurt). Așadar, dacă nota marginală ar fi fost o indicație a lecțiunii diferite din ediția de la Londra, aceasta ar fi trebuit să conțină verbul a ieşi (cf. și B 1688: „și ieși Lia întru

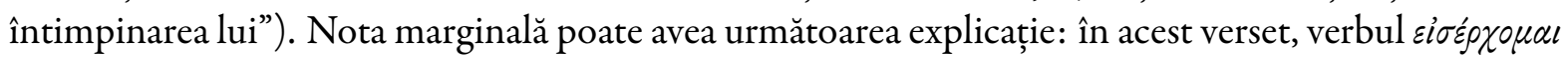
apare, în afară de locul menționat, și la începutul versetului, tradus în ms. 45 prin veni; probabil că revizorul consideră că același verb trebuie să aibă același echivalent în traducerea românească.

d. note marginale care corectează traduceri greșite: 11, 20 „Și trăi Ragav 139 (marginal: 132, cf. gr.

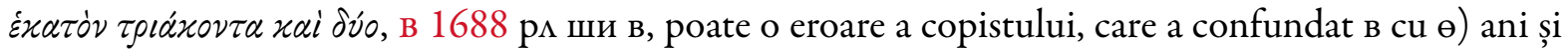

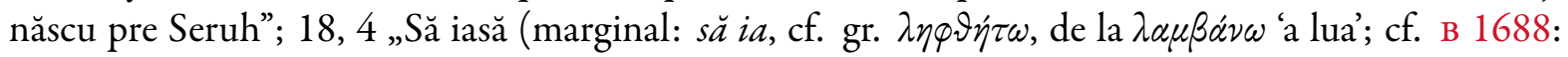
să să aducă; NETS: „do let water be taken”) dară apă și să spêle picioarele voastre și vă răcoriți suptu copaci”; 29, 30 „Și vădzu Domnul Dumnedzău cum să uraște Lia, deșchise zgăul ei; iară Rahil era văduă" (ultimul cuvînt este tăiat cu roșu în text; marginal: stearpă, cf. gr. $\sigma \tau \varepsilon i \tilde{\alpha} \alpha$; de altfel, după cum se arată în context, și Lia, și Rahil erau soțiile lui Lavan); 36, 13 „Și aceștia-s ficiorii lui Raguil: Nahoth, Zare, Some, Moze. Acesta (marginal: aceștia, cf. gr. oṽ $\tau o l$, ca la începutul versetului, unde este redat corect; poate eroare de copiere, nu de traducere) au fostu ficiorii Vasamáth”; 35, 22 „Și fu cîndu sălășlui

${ }^{12}$ Vezi, în acest sens, discuția de la Florescu, 2015, p. 24-26. 
Iacov (marginal: lăcui Israil) întru pămîntul acela, mêrse Ruvim și dormi cu Valá, țiitoarea tătîne-său; și audzi Israil și rău să arătă înaintea lui” (se remediază aici o eroare datorată, probabil, confuziei cauzate de context, unde alternează, ca subiecte, Iacov și Israil; eroarea poate fi a copistului); 40, 13 „Încă 3 dzile și-și va duce aminte faraon de boieriia ta și te va pune pre mărimea păharnicilor și vei da păharul lui faraon pre (marginal: în, cf. gr. ei५; B 1688: în) mîna lui”.

e. în unele cazuri, nota marginală consemnează o variantă de traducere pe care revizorul o consideră mai adecvată în raport cu sursa grecească (fără ca traducerea din text să fie greșită). Emendaţia poate fi de natură gramaticală sau lexicală. Din prima categorie fac parte situații ca: 4, 2 „Și adaose a naște pre fratele lui, pre Ável. Și să făcu Ável păstor de oi, iară Cáin lucra (marginal: era lucrîndu; în textele

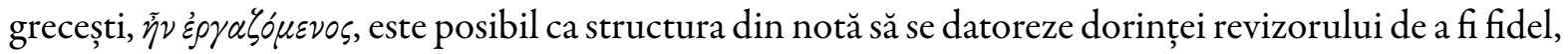
inclusiv sub aspect gramatical, textului grecesc; structura este preluată și în B 1688) pămîntul”" ${ }^{13}$; 6, 13

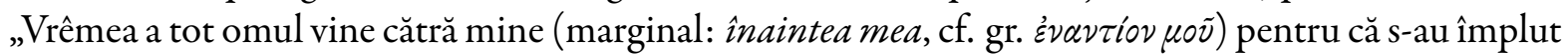
pămîntul de strîmbătate”; 12, 15 „Și o vădzură pre însă boiêrii lui farao și o lăudară (marginal: pre $e a$, marcată printr-o silă roșie deasupra unui punct, ceea ce arată că revizorul consideră că face aici o completare, cf. gr. $\dot{\varepsilon} \pi \dot{\eta} \nu \varepsilon \sigma \alpha \nu \alpha \dot{v} \tau \dot{\eta} \nu$; complementul direct exprimat prin pronume personal de persoana a III-a singular feminin acuzativ era deja exprimat în textul românesc, însă anterior verbului și într-o formă neaccentuată; autorul notei restituie inclusiv topica textului grecesc) cătră farao și o adusără pre

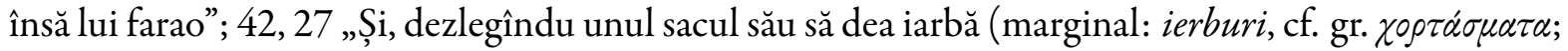
B 1688: hrană) măgarilor săi unde au poposit” (o situație asemănătoare ceva mai jos, la 43, 22 „S,i argintu altul am adus cu noi ca să ne cumpărăm de mîncat", marginal: bucate, cf. gr. $\beta \rho \omega ́ \omega \alpha \alpha \tau \alpha$ 'foodstuff. Used mostly in plural'-Muraoka, s.v.; revizorul observă pluralul din textul grecesc și este nemulțumit de echivalarea prin supin, deși corectă din punct de vedere semantic). Ceva mai complexă este situația din v. 40,16 „Și eu am vădzut vis și mi să părea 3 coșnițe de pîini le rădicam pre capul mieu” (marginal: mă gîndiiam). În textele grecești, aici apare indicativul imperfect mediu $1 \mathrm{sg}$. de la oioual 'to assume as probable' (Muraoka). Probabil revizorul încearcă să găsească o variantă mai apropiată gramatical de ceea ce este în textul sursă (un verb la persoana I). Semantic, echivalarea din notă nu este eronată (este doar inadecvată contextului; cf. și в 1688: mi să părea); în greaca clasică, verbul are și sensul 'think, suppose, believe' (Liddell-Scott).

Uneori, revizorul resimte dificultatea încercării de a concilia două sisteme lingvistice diferite. Așa se întîmplă în v. 35, 3 „Și, sculîndu-vă, să ne suim la Vethil”, unde nota marginală propune lecțiunea sculîndu-ne, în încercarea de a găsi o formă personală adecvată în limba română pentru a exprima acțiunea verbului la o formă impersonală din original (gr. $\dot{\alpha} \nu \alpha \sigma \tau \dot{\alpha} \nu \tau \varepsilon \zeta$, participiu aorist activ).

$\mathrm{Nu}$ întotdeauna nota respectă forma gramaticală din originalul grecesc. De exemplu, în v. 24, 37 „Să nu iêi fămêie fiiului mieu den fêtele hananeilor, întru cari eu sîntu prișleț întru pămîntul lor”, nota propune echivalarea înstriinat pentru prișsleț (considerat, probabil, termen cu o circulație prea restrînsă; DLR indică, pentru acest termen, doar ocurențe din texte aparținînd zonei nordice a teritoriului dacoromân, cu excepția Psaltirii de la Alba-Iulia), deși textul-sursă are, în acest loc, un verb la indicativ prezent 1 singular (cf. și eu sălăşluiesc în в 1688).

Încercări de adecvare la textul-sursă, pe plan lexical, se înregistrează în contextele: 9, 17 „Acesta iaste sămnul făgăduințăi carele am tocmit (marginal: pus) întru mijlocul mieu și întru mijlocul a tot trupul carele iaste pre pămîntu' (verbul din sursă, gr. $\tau$ ' $₹ \varepsilon \mu$, are sensurile 'to put, set, place', revizorul preferă echivalarea printr-un verb cu un sens mai larg); într-un context asemănător: 17, 7 „S,i vom întări (marginal: voi pune) făgăduința mea întru mijlocul tău și întru mijlocul săminției tale după tine" este preferat de revizor tot a pune, pentru a echivala gr. i $\sigma \tau \eta \mu \iota$ 'to stand firm; to stand still; to place' (nota este mixtă, conținînd și o corectură de tip morfologic; în textul grecesc, verbul este la persoana

\footnotetext{
${ }^{13}$ Frâncu (2009, p. 306), citînd inclusiv exemplul din acest verset din B 1688, arată că structura numită de el ,imperfect perifrastic" nu este o creație ad hoc, chiar dacă în textul grecesc există o structură echivalentă, fiindcă astfel de construcții se găsesc și în texte netraduse, și că traducerile din slavonă și greacă au contribuit la stabilizarea acestei forme de imperfect moștenite din latină (cf. și Frâncu, 1983-1984, p. 29).
} 
I singular, nu plural; B 1688: voi întări); 15, 17 „Iară după ce fu soarele cătră apus, pară să făcu și iată, cuptor afumîndu-să, și făclii de foc carele au petrecut pentru acêstea împărțituri” (marginal: despică-

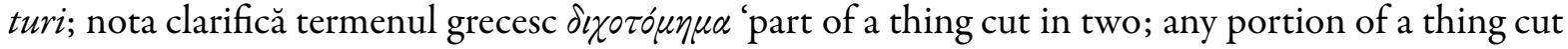
up', propunînd un echivalent mai adecvat contextului, considerat, de altfel, ca atare şi de diortositorii B 1688, care are tot despicături. Muraoka explică: „pieces of sacrificial animal”, cu referire chiar la acest context); 23, 17 „Și iaste țarina (marginal: satul) lui Efron carea era întru peșterea cea îndoită, carele iaste de cătră fața Mamvrí, țarina și peșterea carea era întru ea" (nota propune o altă echivalare pentru

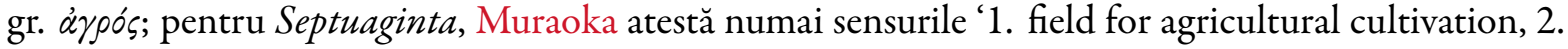
area of land outside of settled area, însă în greaca clasică are și sensul 'sat', cf. Liddell-Scott, s.v.; B 1688 reține echivalarea țarină, cf. „the field of Ephron” NETS); 32, 31 "Și răsări soarele cîndu trecu chipul

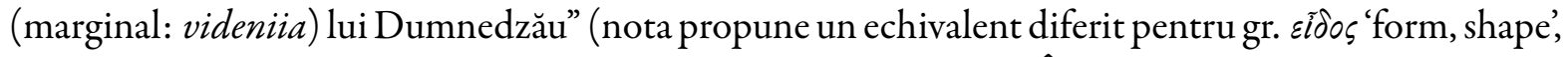
prezent și în 32, 30, context în care ms. 45 traduce prin vidêrea). În v. 50, 11 „Și vădzură lăcuitorii pămîntului Hanaan plîngerea la ariia lui Atad și dziseră: «Plîngere mare aceasta iaste eghiptênilor». Pentru acêea au numit numele locului aceluia Plîngerea Eghiptênilor (marginal: Eghiptului)”, probabil din cauza contextului, traducătorul echivalează eronat sintagma $\pi \varepsilon \dot{\varepsilon} v$ traducerea corectă.

f. alte situații

Cîteva note marginale conțin notații care nu pot fi explicate prin sursele grecești (unele nu pot fi explicate prin nici o sursă). În contextul din v. 24, 47 „Și-i puș cerceii pre brațul (marginal: urechile)

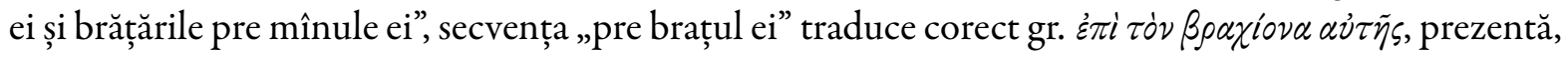
după cum indică aparatul critic al ediției de la Frankfurt, numai în unele versiuni ale Septuagintei; ea lipsește din Sept. Londra. Nici Vulg. Anvers, nici Biblia Ostrog nu justifică prezența substantivului urechile aici; este posibil ca el să-i fi fost dictat adnotatorului de context (prin asocierea cu cerceii). În v. 29, 2 „S, Si vêde, și iată fîntînă în cîmpu”, verbul vêde traduce, corect, gr. óõ̃, indicativ prezent 3 singular de la óó́w (cf. și в 1688: vêde); marginal, este notată varianta vedea, explicabilă prin Vulg. Anvers (vidit) sau prin Biblia Ostrog (oyзрrøжe, cf. văzu ms. 4389). În v. 36, 39 "Și împărăți pentru el Arad, ficiorul lui Varad”, deasupra antroponimului Arad este notată o silă nereluată marginal. Este posibil ca adnotatorul să fi vrut să marcheze astfel faptul că numele apare, în alte versiuni ale textului veterotestamentar, cu altă formă, Adar (Vulg. Anvers) sau Adad (Biblia Ostrog; cf. și ms. 4389). În Fac, 37, 10 „Și-l zavistuiră pre însul frații lui, iară tată-său au păzit (marginal: socotit) cuvîntul”,

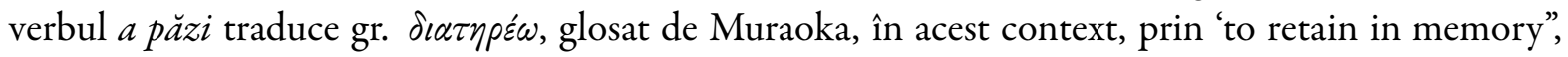
dar care are și sensul 'to have in one's care temporarily'; nota marginală se explică prin apel la Vulgata: considerabat (cf. și ms. 4389: socotiia). În schimb, în 11, 14 „Și trăi Cainan 130 ani și născu (marginal, marcată printr-o silă, completarea: șie) pre Sala”, nota marginală nu se justifică prin raportare la sursele recunoscute sau posibile; este posibil ca adnotatorul să fi fost aici influențat de context, în care apar mai multe fraze cu aceeași structură, iar unele dintre ele conțin și un pronume în dativ (cf. 11, 11 „Și trăi Sim după ce au născut șie pre Arfaxad”; 11, 13 „Și trăi Arfaxadu după ce $i$ să născu Cainan” etc.).

\subsubsection{Note marginale care vizează relația textului cu norma lingvistică}

\section{a. glose care marchează diferențe între norme dialectale sau individuale}

Istoria textului din ms. 45 indică faptul că acesta conține urmele confruntării dintre două norme lingvistice, cea moldovenească, a traducătorului, și cea muntenească, a copistului (și, poate, a unui al doilea revizor). Acest lucru este vizibil inclusiv în unele note marginale prin intermediul cărora se înlocuiesc termeni sau elemente gramaticale marcate dialectal sau care îi sînt mai puțin familiare adnotatorului; la acestea se adaugă elemente de care adnotatorul avea cunoștință, fiindcă circulau în întreaga arie dacoromană, dar pe care le înlocuiește cu elemente mai răspîndite sau mai puțin populare. Cîteva exemple: 3, 24 ,și pusă heruvimii și sabiia cea de pară (marginal: văpaie)” (cu excepția Evangheliei învățătoare a lui Coresi, DLR indică, pentru pară, doar atestări din texte nordice; mai mult, în contexte paralele, psaltirile rotacizante și cea a lui Dosoftei conțin acest substantiv, pe cînd Psaltirea 
de la Alba-Iulia are văpaie); 29, 2 „Și vêde și iată fîntînă (marginal: puț) în cîmpu” (după DLR, puț este frecvent în textele muntenești din epocă, dar apare și în Molitvenicul lui Dosoftei și în Parimiile preste an, inclusiv în sintagma toponimică Puțul Giurămîntului); 32, 25 „Și vădzu cum nu poate și să atinse de lățimea stinghei lui și amorți lățimea stînghei (marginal: coapsei) lui Iacov întru cît să lupta el cu însul" (probabil stînghe i se pare prea regional adnotatorului; substantivul este frecvent şi în textele lui Dosoftei); „Întră tu și toată casa ta în săcriiu” (marginal: raclă; pentru sicriu, DLR amintește sensul 'ladă', cu atestări din Varlaam, Dosoftei etc., aşadar, din arealul nordic); 40, 11 „Și păharul lui faraon în mîna mea; și luai poama (marginal: strugurul)" (după DLR, substantivul poamă cu sensul 'strugure' este specific Moldovei); 37, 30 „Si, luîndu haina lui Iosif, au junghiat un iedu de capră și imară (marginal: întinară) haina cu sîngele" (verbul glosat, a ima, traduce gr. $\mu o \lambda v ́ v \omega$ 'to make physically dirty', cf. unseră в 1688; atît DLR, cît și TDRG indică textele ale lui Dosoftei ca prime atestări în limba literară ale acestui verb și ale derivatelor sale imat, imăciune, iar verbul a ima nu l-am găsit în scrierile recunoscute ale lui Milescu, un indiciu că prezența lor în text i s-ar datora lui Dosoftei, care nu este și autorul gloselor marginale); 24, 37 „Să nu iêi fămêie fiiului mieu den fêtele hananeilor, întru cari eu sîntu prișleț (marginal: înstriinat) întru pămîntul lor" (DLR indică, pentru prişleț, atestări numai din texte nordice, începînd cu Codicele Voronețean); 32, 23 "Și luă pre înșii și trecu puhoiul (marginal:

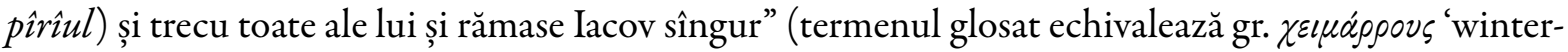
flowing, echivalat cu wadi de Muraoka, în contextul acesta-wadi desemnează o vale care se umple de apă numai ca urmare a unei ploi abundente-; pentru puboi, DLR indică, pentru secolul al XVIIlea, atestări numai din Moldova); 35, 8 „, Si muri Dévorra, mamca (marginal: doica) Revécăi” (mamca traduce gr. $\tau \rho \circ \emptyset o ́ s$ 'wet-nurse'; după DLR, substantivul mamcă, de proveniență ucraineană, este specific Moldovei, așa cum arată și contexte paralele din Pravila Moldovei și din Pravila de la Govora, care conțin mamce, respectiv doice; cf. doica B 1688). În v. 43, 27 „Sănătos iaste tatăl vostru cel bătrîn, carele ați dzis cum custă (marginal: trăiêsste) ?’, nota glosează un termen care circula, în a doua jumătate a secolului al XVII-lea, în Moldova, Banat, Transilvania de sud-est, Crișana (Arvinte, 1988, p. 85); în ms. 45, el este folosit de șapte ori (Fac, 43, 27; Dan, 12, 7; Iov, 21, 7; 27, 15; 2Par, 23, 11; 3Rg, 1, 25; $P s, 48,8$ ), fiind glosat prin trăieșste doar în două locuri (aici și în $3 R g$ ).

În v. 47, 9 „Dzilele anilor vieții mêle carele prișleșescu (marginal: lăcuiesc), 130 ani; mici și rêle s-au făcut dzilele anilor vieții mêle, $n$-au agiunsu la dzilele anilor vieții părinților miei care dzile au prișleșit (marginal: au lăcuit)", ambele note sînt marcate prin sile scrise cu negru, iar notațiile sînt de altă mînă. Verbul a prişleşi din text echivalează corect gr. $\pi \alpha \rho o n \varepsilon \dot{\varepsilon} \omega$, '1. to live in the proximity of...; 2. to stay as (short term) resident alien; to dwell (in general)'; la sensul 2, Muraoka amintește acest context din 47, 9, spunînd că este, cel mai probabil, o traducere mecanică a contextului ebraic, care înseamnă 'j’ai passé sur la terre', cf. Bible d'Alexandrie. DLR indică, pentru a prişleşi, sensul 'a se stabili în altă parte; a se strămuta, a se înstrăina', cu atestări numai din B 1688. În manuscris, verbul a prişsleși are nouă ocurențe (numai în Facerea și Ieșirea), singurele glosări sînt cele de mai sus; din aceași familie lexicală mai sînt întîlniți aici termenii prişleț (12 ocurențe, numai în Pentateub) și prişleșenie (6 ocurențe, exclusiv în Facerea și Ieșirea). În в 1688, verbul în discuție este înlocuit prin a locui, a se sălăşlui sau, cum este cazul la 47, 9, a nemernici. Interesant de remarcat, pentru relația dintre cele două texte (ms. 45 și B 1688), este faptul, bizar, că a prişleși apare în textul tipărit în contexte unde, în ms. 45, avem un verb echivalent (cf. Jud, 5, 17, a nemernici în ms. 45; 1Par, 5, 26, a inmuta, glosat înstriina, în ms. 45; 1Par, 9,1 , a înstriina în ms. 45), ceea ce arată că cercetările despre relaţia dintre cele două texte sînt doar la început și că problema poate fi tranșată numai prin compararea lor exhaustivă. De notat că traducerea muntenească din ms. 4389 nu conține nici unul dintre termenii în discuție.

În contextul din v. 48, 1 „Și fu după cuvintele acêstea și să porînci lui Iosif că tată-său să dodăiêște

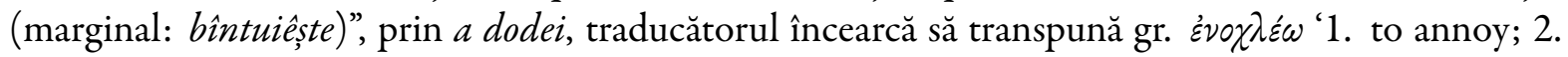
pass. to be ill'; Muraoka indică, pentru acest context, al doilea sens (verbul grecesc este aici la indicativ prezent pasiv); cf. „Your father is ill” NETS; „ægrotaret pater suus” Vulg. Anvers; „tată-său slăbêște” ms. 4389. Se pare că traducătorul nu a identificat corect sensul contextual și a transpus eronat prin $a$ 
dodei 'a necăji', preluat și de в 1688. Și mai stranie este nota marginală, care propune verbul a bîntui, pentru care dicționarul lui Scriban indică sensul 'a vătăma', iar Cihac, 'a necăjii. Verbul în discuție apare de 22 de ori în ms. 45 (fără ca utilizarea sa să fie restrînsă la o anumită parte a textului), dar numai în Pentateuh este glosat consecvent (prin a mînia, a supăra, a bîntui la Num, 14, 11, unde a bîntui actualizează sensul 'a supăra'); similar, substantivul dodeială apare de 10 ori în text, glosat în primele cărți prin învăluială, îngustare și în Sir, 2, 1 prin bîntuială. Observațiile ar indica existența unei rupturi, la nivelul manuscrisului, între Pentateuh (sau, să spunem, prima parte, pînă la 1 Par) și partea a doua, nu doar în ceea ce privește sursele reviziei (așa cum arată prefața), ci și în privința tratamentului regionalismelor ${ }^{14}$.

Deși nu este vorba despre confruntarea între dialectele literare, ci mai degrabă despre cea dintre două norme individuale, vom aminti aici și situația de la v. 21, 27 „Și luă Avraam oi şi vițăi și dêde lui Aviméleh; și au făgăduit amîndoi făgăduință”, unde făgăduință este glosat prin făgăduire.

Construcția formată din interjecția ia și imperativul persoana a II-a sau prezentul persoana I plural al verbului a îmbla sînt folosite în textele lui Dosoftei pentru a exprima îndemnul (cu sensul 'hai, haideți'). Ele apar și în ms. 45, fiind considerate de N. A. Ursu un argument în favoarea paternității mitropolitului moldovean asupra reviziei traducerii lui Milescu (apud Arvinte, 1988, p. 80); în orice caz, construcțiile de acest tip nu sînt frecvente în epocă (nu sînt înregistrate în Gramatica limbii române de C. Frâncu, care vorbește numai despre formele de tipul blăm, blați). În ms. 45, ele sînt glosate marginal prin forme ale verbului a veni: 37,12 „Nu frații tăi pascu la Sihem? Ia-mblă (marginal: vino) și te voi trimite cătră înşii”" (secvența glosată echivalează gr. $\delta \varepsilon \tilde{u} \rho$, care are aici rolul unei interjecții, cu sensul 'let's, come'); 37, 19 „Acum, dară, ia-mblați (marginal: veniţi) să-l omorîm pre el și să-l aruncăm într-una de gropi”.

Conjuncția subordonatoare să 'dacă, despre care Frâncu (2009, p. 334) spune că, la mijlocul secolului al XVII-lea, era întîlnită mai ales în texte reprezentînd graiurile nordice, în sud fiind concurată puternic de de (idee exemplificată prin contexte paralele din Cazania lui Varlaam și cazaniile muntenești ulterioare), este glosată adesea prin $d e$ (uneori cu $d$ dur, specific Munteniei: $d \breve{a}$ ): 38, 17 „S, i ea dzise: «Să (marginal, marcată printr-o silă deasupra consoanei $s$, nota $d$, implicînd lecțiunea $d \breve{a}$ ) vei da arravon pînă vei trimite»”; 42, 20 „Și pre fratele vostru cel mai tînăr să-l aduceți la mine și să vor încrêde cuvintele voastre, iară să (marginal: de) nu, veți muri” (la fel: 43, 3; 43, 5).

\section{b. glosări ale grecismelor}

Grecismele preluate direct din textul tradus sînt glosate marginal: 14, 6 „S,i pre horei, pre cei den Munții Siir pînă la tereminthos (marginal: stăjari; cf. gr. $\tau \varepsilon \rho \varepsilon \mu i v \vartheta o \varsigma)$ a i Faran”; 20, 14 „Și luă Aviméleh

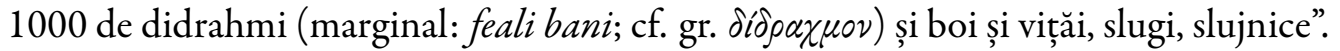

c. corecturi care privesc morfologia sau grafia textului: 42, 2 „Pogorîți acoló și cumpărați noă de acoló puțini (marginal: puține) bucate pentru ca să trăim și să nu murim”; 41, 22 „Și iată, ca cîndu are fi 7 spice să suia dentru o rădăcină, plini și buni (marginal, corectura $e$, marcată printr-o vrahie deasupra ultimelor slove din cuvintele plini și buni, propunînd lecțiunile: pline, bune; în acest caz, traducerea păstrează genul adjectivelor din original, masculin plural); 2, 14 „S, Si rîul al treilea - Tigris; acesta ce mergea înaintea (marginal: înainte) în preajma Assiriilor”; 6, 16 „Și ușea săcriiului o vei face den coaste, cu beciuri dedesuptu, cu doaă rînduri de podină și cu 3 rînduri îl vei face pri-nsu (în text, scris при"c8; marginal: npE"c8)”. Alte notații reiau cuvinte scrise neclar în text $(9,24 ; 29,27 ; 29,32)$.

\subsubsection{Semnalări marginale sau in text}

În unele cazuri, un anumit cuvînt din text este marcat prin sile, reluate marginal, dar fără nici o explicație. În v. 6, 16 „S,i tot adunîndu-l vei face săcriiul”, conjuncția coordonatoare nu corespunde surselor grecești (cf. și в 1688: „Adunîndu-l vei face sicriiul”), ci doar textului slavon; poate că asta vrea să indice adnotatorul. În v. 35, 13 „Sui-să Dumnedzău de la însul, dentru locul carele au grăit cu însul”, pe ultima

\footnotetext{
${ }^{14} \mathrm{O}$ inconsecvență în manuscris se înregistrează și la nivel grafic, în ceea ce privește notarea vocalelor $a$ și $\hat{\imath}$; dacă pînă la $3 R g$ slova $z$ este folosită cu ambele valori, de la $4 R g$ încolo se observă notarea consecventă a lui $\breve{a}$ prin $z$ și a lui $\hat{\imath}$ prin $b$.
} 
silabă a prepoziției dentru este o silă, reluată marginal, fără altă explicație; probabil că adnotatorul nu este de acord cu echivalarea prepoziției gr. $\check{\varepsilon} \chi$, în acest context, prin dentru, ci mai degrabă prin den (asta ar explica faptul că este marcată numai ultima parte a cuvîntului); situație similară la 9, 15 .

\subsection{Notele marginale din cartea lui Iov}

Am luat în discuție și inventarul notelor marginale din această carte pentru a observa dacă pot fi identificate aici aceleaşi tipuri de notații ca în prima carte a Pentateubului. În cartea lui Iov (care, în ms. 45, are 23 de pagini, de la p. 422 la p. 444) există 93 de notații marginale, clasificabile astfel:

\subsubsection{Note care trimit la hipertextul biblic}

Există în cartea lui Iov 37 de note care consemnează trimiteri biblice: la alte cărți, în interiorul aceleiași cărți sau mixte. Nu găsim aici, însă, comentarii biblice marginale și nici indicații care să privească pasaje mesianice; indicațiile rezumative se găsesc în manuscris numai pînă la cartea a patra a Pentateubului.

\subsubsection{Note marginale care privesc relatia textului cu sursele}

\section{a. note care consemnează omisiuni de traducere sau de copiere:}

- de aceeași mînă, marcate prin sistemul anunțat în prefață (silă cu punct dedesubt, cu roșu) sau doar cu sile: 1,3 ,Și era dobitoacele lui oi 7000, cămile 3000, părechi de boi 500, măgărițe (marginal: păscătoare, cf. gr. vouádec) 500”; 1, 7 „Împregiurînd pămîntul și îmblînd (marginal: cea, cf. gr.

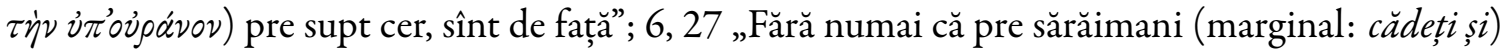
vă săltați preste priêtenul vostru”; 7, 10 „Nici să va mai întoarce la a sa (aici, secvența $a$ sa, omisă, probabil, a fost completată deasupra rîndului și este reluată marginal, mai clar) casă”; 31, 22 „Să să dăsparță, dară, umărul mieu dentru încheietură și brațul mieu (marginal: din cot) să să surpe”; 31, 25 „Sau de m-am veselit făcîndu-mi-să avuție multă, sau de am pus (marginal: şi, echivalînd un $\delta \dot{\varepsilon}$ care rămăsese netradus) mîna mea și preste cei nenumărați”;

- de altă mînă: 17, 11 „Zilele mêle trecură cu alergare și să rumpseră (marginal, de altă mînă, cu altă cerneală: mădulările) inimii mêle”; 22, 9 „Și văduile le-ai trimis deșarte (marginal, de altă mînă: „și pre sirmani i-ai chinuit”)”; 27, 5 „Nu-mi fie (marginal, de altă mînă: mie) drepți pre voi a răspunde”; 28, 6 „Locul samfirului - pietrile lui; și lutul - aurului (marginal, de altă mînă: lui)”; 33, 21 „Pînă unde să vor putrezi lui pielíțele și va dovedi (marginal: oasele, omisiune a copistului) lui deșarte".

În 32, 20 „Grăi-voi, pentru ca să mă odihnesc dășchidzînd budzele” (marginal, de altă mînă: mêle), completarea nu urmează Sept. Frankfurt (unde nu există pronume; cf. deșchizînd buzele B 1688), ci poate fi justificată doar de utilizarea Vulgatei: „labia mea” sau prin Biblia Ostrog (oycma cu), cf. „,̦i-mi voiu deșchide gura” ms. 4389.

b. note care marchează un element ce nu există în textul grecesc tradus. Unele secvențe „în plus” față de sursă vin, de fapt, din încercarea de a concilia cele două sisteme lingvistice, al limbii sursă și al limbii în care se traduce; ele sînt încadrate între semiparanteze pătrate (în prima parte a textului, acest marcaj era folosit pentru a indica secvențele în plus în Sept. Londra față de Sept. Frankfurt) și prezența lor este indicată marginal printr-o silă; alte secvențe care nu se regăsesc în textul grecesc sînt explicabile prin apelul la alte surse (textul latin şi cel slavon). Exemple: 11, 13 „Pentru că tu, dă ai fi pus curată inima ta și să verși mîinile Łtale cătră el” (cf. „cum manus tuus” Vulg. Anvers, pyun cвou Biblia Ostrog); 14, 5 „Măcară și o zi \va fi $\rfloor$ viața omului pre pămînt”, situație similară la 34, 26; 24, 16 „Săpat-au întru întunêrec casă; dzua au pecetluit pre sine și n-au cunoscut lumină” (conjuncția lipsește din textul grecesc, dar apare în cel latin). În v. 38, 38 „Și iaste răvărsat ca pămîntul cu pulberea, și l-am lipit pre el ca pre o piatră cu patru muchi [de piatră ’", sintagma dintre semiparantezele pătrate este marcată prin sile reluate marginal, fără alte explicații; notația indică faptul că sursele nu justifică repetarea acestui substantiv.

c. note marginale care corectează traduceri greșite: 2,9 "Și tu sîngur întru putrejune a viermilor ședzi, mîind descoperit, și eu - rătăcită și slujnică, loc den loc împregiurînd și den casă în casă, așteptînd 
soarele cînd va apune, pentru ca să mă odihnesc de ostenêlele mêle și de durori carele astădzi (marginal: acum, cf. gr. $\nu \tilde{v} v$; toate posibilele surse conțin lecțiunea „acum”, nu „astăzi”) pre mine mă țin”. În v. 39,15 „Și au uitat că piciorul va răsîpi și jiganiile cîmpului vor (marginal: va) călca”, nota corectează lecțiunea din text conform sursei grecești traduse. Întrebarea este de ce apare pluralul în verset. Dintre sursele consultate, doar unele versiuni ale Vulgatei (altele decît Vulg. Anvers) au aici pluralul conterant. Dintre textele românești, в 1688 preia pluralul din ms. 45, păstrat, la rîndul său, și de Biblia lui Samuil Micu. Sau traducătorul (ori copistul) ms. 45 folosește pluralul sub influența contextului, sau textul are şi o sursă latinească, alta decît Vulg. Anvers.

$\mathrm{Nu}$ toate erorile de traducere/copiere sînt corectate. De exemplu, în versetul 27, 18 „Nu să istovi casa lui ca niște molii și ca niște păianjini”, negația de la început nu se justifică prin nici una dintre surse (nici grecească, nici latină, nici slavonă), și nici nu este corectată. Cf. в 1688: „Și să va istovi casa lui ca niște molii”; ms. 4389: „Și casa lui se va umplea ca de molii”.

d. note marginale care consemnează variante de traducere mai adecvate în raport cu sursa. În v. 13, 8 „Au veți îndoi? Voi și voi (marginal: aceștia) judecători vă faceți”, pronumele personal voi echivalează

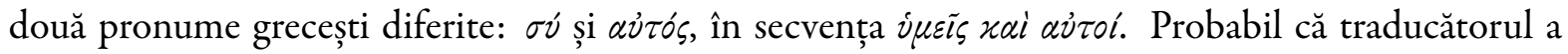
fost încurcat de particula «ai și a vrut să respecte topica originalului. Cf. B 1688: „Voi și înşivă” (transcris greșit în ediția din 1988 a Patriarhiei: „voiși înșivă”). În v. 24, 20 „Și ca o ceață a roaăi nevăzută s-au făcut. Și să deade lui carele au poftit (marginal: făcut), și să să zdrobască tot strîmbul, atocma cu un lemnu nevindecat", glosa consemnează sensul adecvat contextual al gr. $\pi \rho \dot{\sigma} \sigma \sigma \omega$ 'to do' (Muraoka), cf. și в 1688 au făcut. În greaca clasică, $\pi \rho \alpha ́ \sigma \sigma \omega$ are și sensul 'to obtain, demand' (LiddellScott), pe care traducătorul îl echivalează aici, dar care nu este potrivit contextului (cf. și NETs: „may what he did be paid back to him”). În v. 39, 1 „Dă ai cunoscut vrêmea nașterii pietrii țapcerbului (marginal, este propusă lecțiunea țapcerbilor, prin înlocuirea ultimelor două silabe ale cuvîntului)? Și ai păzit chinurile cerbilor?", nota emendează textul conform versiunii din Septuaginta, unde este pluralul (dar aparatul critic al Sept. Frankfurt menționează și versiuni cu singularul). B 1688 preia întocmai textul din ms. 45, corectat apoi în Biblia Micu (cerbilor). În 33, 28 „Mîntuiêște sufletul mieu, ca să nu viu la pierire (marginal: stricăciune), și viața mea lumină va vedea”, nota propune o

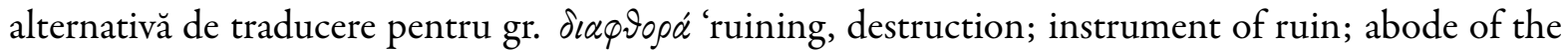
dead' (Muraoka), 'destruction, ruin' (Liddell-Scott); в 1688 reține varianta peire. În v. 5, 23 „Căci cu pietrile cîmpului (marginal: țarenii) - făgăduința ta, și jiganiile țarenii vor împăca ție”, adnotatorul remediază, probabil, ceea ce el consideră a fi o infidelitate față de text; substantivele cîmp și țarină, la

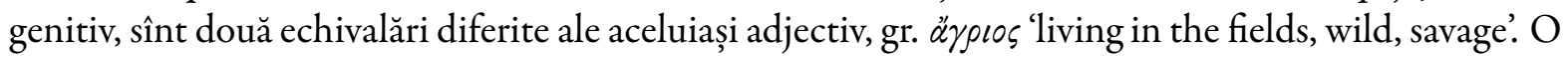
situație similară se înregistrează în 8,9 , unde mreajă este glosat prin cursă, fiindcă în versetul anterior mreajă fusese deja utilizat pentru a echivala alt cuvînt grecesc.

În 7,8 „Nu mă va mai vedea ochiul celui ce mă vêde, ochii tăi - întru mine, și nu voi mai fi” (marginal: încă mai sînt), nota indică varianta corectă în raport cu Septuaginta, unde apare secvența oủx

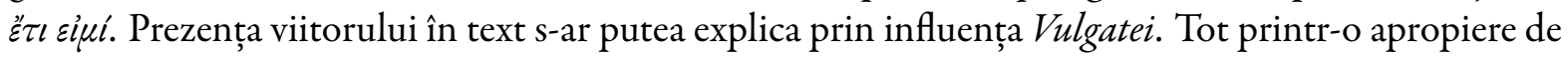
originalul grecesc s-ar putea explica nota de la v. 9,5 „Cela ce vechêște munții și nu știu; cel ce-i surpă pre înși cu mînie (marginal: urgie, cf. gr. ó $\rho \gamma \dot{)}$ ). În 27, 7 „Însă nu, ce fie nepriêtenii miei ca surparea celor necurați (marginal: necredincioşi)", nota propune o echivalare mai precisă a gr. $\dot{\alpha} \sigma \varepsilon \beta \dot{\eta} \varsigma$ 'ungodly, impious'.

Situația inversă se întîlnește la v. 29, 6: „Cînd să vărsa căile mêle cu unt și munții miei să vărsa (marginal: turna) cu lapte”; textul grecesc are acelaşi verb ( $\chi \dot{\varepsilon} \omega$ 'to pour, shed; spread', Muraoka) în ambele poziții, tradus consecvent prin a vărsa în textul ms. 45 (la fel în B 1688). Biblia Ostrog are și ea același verb în ambele poziții (обливатu), echivalat prin a vărsa în ms. 4389. În schimb, Vulgata are lavabam și fundebat ('to wash; to wet, moisten', dar și 'to pour', old). Ori adnotatorul din ms. 45 a vrut să varieze, ori a avut în vedere modelul latin.

Nu întotdeauna varianta propusă marginal este corectă. Astfel, în v. 33, 27 „Și apoi, atuncea va trimite om, el șie dzicind: În ce fêl făcea (marginal: trimetea)!", primul verb (va trimite) este, probabil, rezul- 
tatul unei erori de copiere, fiindcă în Septuaginta se găsește $\dot{\alpha} \pi \propto \mu \varepsilon \dot{\mu} \mu \psi \varepsilon \tau \alpha \iota$,va mustra” (în Vulg. Anvers, respiciet, cf. și ms. 4389: „Va bănui omul însuși pre sine”, B 1688 „atuncea să va huli omul însuș luiș”). În schimb, cel de-al doilea verb este corect echivalat în text, din punct de vedere lexical (gr. $\sigma \nu \nu \tau \varepsilon \lambda \varepsilon ́ \omega$ 'to complete, finish; to make an end, destroy; to perpetrate', a face în ms. 45), însă nu și gramatical (în textul grecesc, e la persoana 1 singular, tradus în română făcea). Nota marginală perpetuează eroarea gramaticală, dar nu se justifică nici ca opțiune de echivalare; poate că ea este redactată sub influența erorii din prima parte a versetului. În B 1688, eroarea gramaticală este corectată: ,,în ce fêl făceam”.

e. alte situații

Variantele propuse în unele note marginale nu sînt justificate dacă le raportăm la sursele despre care se vorbește în Cuvînt înainte cătră cititori. În 1, 1 „Om oarecare era în țara Avsitidei, căruia numele

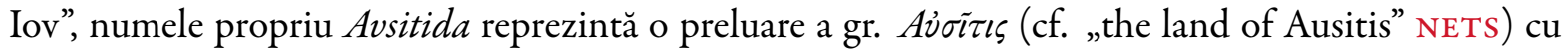
tot cu terminația de dativ, la care este adăugată desinența de genitiv românească. Nota marginală (ditei) propune înlocuirea ultimelor două silabe ale cuvîntului, propunînd secvența Avsiditei. Varianta cu $d$ nu este înregistrată în sursele grecești, iar tradițiile latină și slavonă propun, pentru desemnarea respectivei țări, numele Hus (cf. ms. 4389: „Era un bărbat în țara Husului”). Singurul loc în care am întîlnit forma cu $d$ în loc de $t$ este aparatul ediției critice a parimiarului slavon (Zdenka Rivarova, Zoe Hauptova, Grigorovicev Parimejnik, 1. Tekst s criticiki aparat, Skopje, 1998), care înregistrează (p. 69v ) astfel de forme în unele manuscrise (dar Avsitidii în Parimiile preste an). Poate că metateza propusă de adnotator are la bază o versiune anterioară (nu neapărat românească) cunoscută de el a cărții lui Iov.

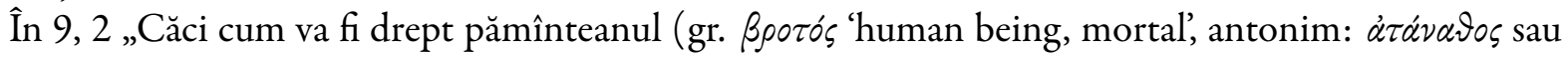

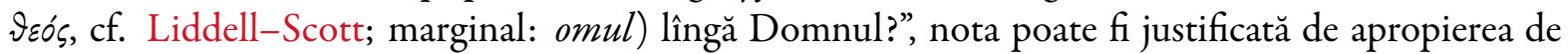
textul latin (care are homo; cf. și ms. 4389: omul); în general, pentru exprimarea condiției de muritor, textele românești folosesc substantivul pămîntean (cf. și Parimiile preste an, III, $95^{\mathrm{v}}$, unde peminteanii este folosit pentru a echivala gr. vroti-scris cu caractere chilice-din imnul reprodus în paralel).

Prin nici o sursă nu se justifică adnotarea de la v. 31, 30 „Bine-i să audză, dară, urêchea blăstămul mieu și să mă povestesc, dară, de cătră nărodul (marginal, de altă mînă: Domnul) mieu chinuindu-mă”; termenul din glosă nu apare nici în ediții ulterioare și nici în textele paralele. Probabil că nota este rezultatul unei confuzii, al unei interpretări eronate a contextului.

\subsubsection{Note marginale care privesc relația textului cu norma lingvistică}

a. glose care marchează diferențe între norme dialectale sau individuale: 6, 26 „Pentru că nu de la voi vîrtute cer, nice certarea (gr. '̇̉ $\bar{\varepsilon} \chi \chi \circ \varsigma_{\text {' }}$ act of questioning; that which deserves open criticism'; marginal: mustrarea) voastră cuvintele mêle vor înceta” (cf. și B 1688, ms. 4389 mustrarea); 16, 13 „Puseră-mă ca un străjar (marginal: strajnic), încungiurară-mă cu fușturi, lovind întru mușchii miei” (după DLR, străjer este atestat mai ales în texte moldovenești, în timp ce strajnic apare în texte muntenești); 28, 12 „Și înțelepțiia (marginal: înțelepciunea) de unde s-au aflat”; 30, 30 „Și piêlea mea s-au ucis tare și oasele mêle să ojojiră de arșiță” (marginal: arsură); 41, 16 „Inima lui iaste înfiptă ca o piatră și stă ca un ilău (marginal: o năcovalnă) nerăsărit".

b. corecturi care privesc morfologia sau grafia textului: 12,16 „Dă va opri apa, va usca pămîntul; iar de o va slobodzi, au pierdut pre el zdrobindu-l” (marginal este reluată secvența „pre el”, scrisă defectuos în text); 18, 21 „Preste însă au suspinat cei de apoi, iară (marginal: pre) cei dentîi ii cuprinse minune” (nota marchează exprimarea clară a complementului direct; similar la 24, 1); 29, 2 „Cine m-are (marginal: m-ar) pune pre lună înaintea dzilelor cărora Dumnedzău m-au cruțat” (Frâncu, 2009, p. 316, arată că inovația ar apare întîi în Țara Românească, în secolul al XVII-lea, și abia în secolul următor se extinde și în restul teritoriului; așadar, aici se înlocuiește o formă percepută ca regională); 31, 38 „De au suspinat pămîntul vreodinioară asupră-mi sau de rozoarele ei (marginal: lui; în textul grecesc, pronumele este la genul feminin) au plînsu toate odată” (o situație similară la 31, 39); 39, 13 „Aripa celor ce să veselesc neélassa, să (marginal: $d \breve{a}$ ) va zemisli asída și nessa?”. 


\subsubsection{Semnalări marginale sau în text (färă alte explicaţii)}

41, 16 „Inima lui iaste înfiptă ca o piatră”; 34, 26 „Și au stinsu pre cei necurați și văzuți înaintea lui 【sînt ]”; indică prezența unui element în plus în textul românesc față de sursa grecească.

\section{Concluzii}

Studiul de mai sus a pornit de la două premise: istoria textuală confuză a primei traduceri românești a Vechiului Testament în versiunea Septuagintei, ajunsă la noi într-o versiune revizuită conținută în ms. 45 de la Biblioteca Filialei din Cluj a Academiei Române, și faptul că notele marginale ale acestui text, care nu au fost studiate pînă acum în totalitatea lor, ar putea oferi indicaţii despre etapele constituirii textului. Avînd în vedere afirmația din Cuvînt înainte cătră cititori referitoare la existența unei discontinuități în consultarea surselor grecești în timpul efecturării acestei revizii, am ales să compar notele marginale din cartea Facerii cu cele din Iov, urmărind tipologia notelor marginale, marcarea lor în text, eventuale indicii legate de identitatea adnotatorului.

În prefața manuscrisului se anunță existența mai multor tipuri de note (completări, trimiteri biblice, indicarea lecțiunilor diferite în alte surse, glose) și sînt decodate semnele grafice utilizate pentru marcarea lor, demonstrînd existența unui sistem grafic coerent și relativ consecvent. Studiul inventarului notelor marginale din cele două cărți biblice a arătat că există note care îndeplinesc și alte funcții decît cele amintite.

Am identificat trei mari categorii de note marginale: note care trimit la sistemul biblic, note care privesc relația cu sursele traducerii (declarate sau nu), note care vizează diferențe de norme lingvistice (glosele propriu-zise). La acestea se adaugă ceea ce am numit „semnalări”, adică prezența marginală a unor semne grafice care marchează existența unei probleme într-un anumit context, fără alte indicații.

Cele trei mari tipuri de note marginale sînt prezente în ambele cărți biblice vizate de studiul de față. În Facerea, primul tip este actualizat prin trimiteri biblice (la alte cărți biblice sau la aceeași carte, prin indicațiile sus / jos), indicații rezumativ-orientative, un amplu comentariu biblic, indicarea pasajelor cu interpretare mesianică; în Iov se regăsește numai categoria trimiterilor biblice, confirmînd ceea ce se spune în prefață (că la începutul traducerii Milescu a făcut mai multe notații pe marginea textului tradus, dar a abandonat această operațiune pe parcurs); notele rezumative și indicațiile mesianice se regăsesc numai în primele patru cărți ale Pentateubului.

Notele marginale care privesc relația dintre textul ms. 45 și sursele traducerii (cele două ediții ale Septuagintei, cea de la Frankfurt, 1597, indicată ca sursă a traducerii și a reviziei de la 1Par încolo, și cea de la Londra, 1653, indicată ca sursă folosită de revizor pînă la 1Par; Biblia Ostrog, 1581, o ediție a Vulgatei) conținute în Facerea se referă la: omisiuni ale traducătorului sau ale copistului; secvențe în plus în Septuaginta de la Londra față de ediţia de la Frankfurt; lecțiuni diferite în cele două texte grecești; corecturi ale traducerilor eronate; încercarea de adecvare a textului românesc la sursa grecească, la nivel lexical sau gramatical (morfologic). În cartea lui Iov, unde Sept. Frankfurt este folosită și la revizie, lipsesc referirile la altă ediție a textului septuagintal, notele marginale vizinnd numai conformitatea cu unica sursă grecească: omisiuni, elemente existente în ms. 45, dar fără corespondent în sursă (conjuncții, copule), traduceri eronate, variante mai adecvate faţă de sursă din punct de vedere lexical sau morfologic.

A treia categorie de note marginale, prezentă în ambele cărți biblice, rezultă din confruntarea dintre normele lingvistice regionale diferite; acestea sînt glose propriu-zise (înlocuirea unui regionalism-lexical sau gramatical—specific zonei nordice a teritoriului dacoromân cu un termen cu circulație mai largă sau cu un muntenism; traducerea grecismelor sau a ebraismelor preluate din Septuaginta) sau corecturi morfologice sau grafice.

Am remarcat, de asemenea, faptul că în ambele cărți biblice apar atît note scrise de aceeași mînă ca textul, cît și note de altă mînă, ulterioare copierii de către Dumitru din Cîmpulung; acestea din urmă au un pronunțat caracter muntenesc. Poate că studiul lor exhaustiv, la nivelul lexicului sau al inserției textuale, ar aduce indicii referitoare la identitatea revizorului muntean. De asemenea, am mai observat că multe dintre note glosează un moldovenism printr-un muntenism, ceea ce indică faptul că ele nu îi aparțin 
revizorului moldovean presupus de N.A. Ursu, care-l identifică în persoana mitropolitului Dosoftei. Pe de altă parte, este îndoielnică ipoteza unei intervenții masive în text a copistului, atît de pronunțată încît să fi generat inclusiv note marginale, ceea ce ar însemna că, de fapt, traducerea lui Milescu a suferit, înainte ca textul să fie copiat de Dumitru, două revizii (dacă o admitem pe cea a lui Dosoftei), la care se adaugă cea a persoanei care redactează notele marginale ulterioare copierii de către Dumitru din Cîmpulung.

O direcție de cercetare deschisă de articolul de față vizează, așadar, studiul exhaustiv al notelor marginale din manuscris, care ar oferi informații mai utile în stabilirea istoriei textuale a traducerii lui Milescu; aceasta pare mai complicată decît ceea ce știm pînă în prezent.

\section{Bibliografie}

\section{A. Izvoare}

в 1688 = Biblia adecă Dumnezeiasca Scriptură a ceii Vechi și ale ceii Noao Leage, toate care s-au tălmăcit dupre limba elinească spre înțelegerea limbii rumânești, cu porunca preabunului Domn Ioan Şărban Cantacozino Basarabă Voievod (...), București, 1688.

Biblia Micu = Biblia, adecă Dumnezeiasca Scriptură a legii vechi și a ceii noao, toate care s-au tălmăcit de pre limba elinească pre ințelesul limbii românești [...]. Cu blagoslovenia mării sale prealuminatului și preasfințitului domnului domn Ioan Bob, vlădica Făgărașului [...], Blaj, 1795; ediție jubiliară în reproducere anastatică și transcriere interpretativă, coord. Ioan Chindriş și Eugen Pavel, Roma, 2000.

Biblia Ostrog = Библиц сиречь книгъ Ветхаго и Новаго Завета по цазыкоу словенскоу (...), Ostrog, 1581.

MLD = Monumenta lingue Dacoromanorum. Biblia 1688. Editura Universității „Alexandru Ioan Cuza”, Iași. Pars I. Genesis, 1988; Pars II. Exodus, 1991; Pars III. Leviticus, 1993; Pars IV. Numeri, 1994; Pars V. Deuteronomium, 1997; Pars VII. Regum I, Regum II, 2008; Pars VIII. Regum III, Regum IV, 2014; Pars IX. Paralipomenon I, Paralipomenon II, 2011; Pars $X_{2}$. Iob, 2012; Pars XIV. Ieremia. Lamentationes Ieremie, 2014; Pars XX. Sapientia, Ecclesiasticus, Susanna, De Belo sive Dracone Babylonico, 2014; Pars XXII. Iosephus ad Machabeos, 2013.

Ms. 45 = Biblioteca Filialei Cluj a Academiei Române, fondul Blaj, Manuscrisul românesc nr. 45 [c. 1683-1686]. Conține traducerea integrală a Vechiului Testament, efectuată de Nicolae Milescu și revizuită de un anonim moldovean (probabil Dosoftei) în a doua jumătate a secolului al XVII-lea.

Ms. 4389 = Biblioteca Academiei Române, Manuscrisul românesc nr. 4389 [c. 1665-1672]. Conține traducerea integrală a Vechiului Testament, efectuată după slavonă și latină de un anonim muntean (probabil Daniil Andrean Panoneanul) în a doua jumătate a secolului al XVII-lea.

NETS = A New English Translation of the Septuagint and the other greek translations traditionally included under that title, Albert Pietersma and Benjamin G. Wright (editors), International Organization for Septuagint and Cognate Studies, Oxford University Press, 2007.

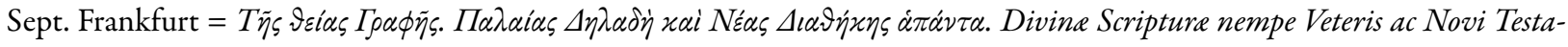
menti omnia, Grece, a viro doctissimo recognita et emendata, variisque lectionibus aucta et illustra, Frankofurti ad Mœnum, apud Andreæ Wecheli hæredes, 1597.

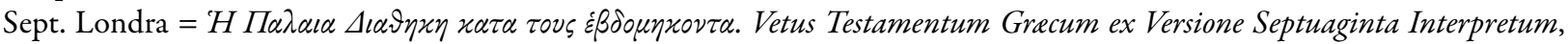
Londini, Excudebat Rogerus Daniel, 1653.

Vulg. Anvers = Biblia ad vetustissima exemplaria castigata [...], Antwerpiæ, ex officina Christophori Plantini, 1565

\section{B. Dictionare}

DLR = Dicționarul limbii române (ediție anastatică), Editura Academiei Române, 2010

Liddell-Scott = A Greek-English Lexicon, compiled by Henry George Liddell and Robert Scott, revised and augmented by Sir Henry Stuart Jones, with the assistance of Roderick McKenzie and with the cooperation of many scholars. With a revised supplement, Oxford Clarendon Press, 1996.

Miklosich = Lexicon Paleoslovenico-Greco-Latinum. Emendatum auctum edidit Fr. Miklosich, Vindobonæ, Guilelmus Braumueller, 1862-1865.

Muraoka = T. Muraoka, A Greek-English Lexicon of the Septuagint, Peeters, Louvain, 2009.

OLD $=$ Oxford Latin Dictionary, edited by P.G.W. Glare, Oxford Clarendon Press.

TDRG = Hariton Tiktin, Rumänisch-Deutsches Wörterbuch. 3. überarbeitete und ergänzte Auflage von Paul Miron und Elsa Lüder, Band I. $A-C$, Clusium, Cluj-Napoca, 2000; Band II. D-O, Clusium, Cluj-Napoca, 2003, Band III. P-Z, Clusium, Cluj-Napoca, 2005. 


\section{Literatură secundară}

Andriescu, Al. (1988). Locul Bibliei de la București în istoria culturii, literaturii și limbii române literare, în MLD, Pars I. Genesis, Iași, p. 7-45.

Arvinte, V. (1988). Studiu lingvistic asupra primei cărți (Facerea) din Biblia de la București (1688), in comparație cu Ms. 45 și Ms. 4389, în MLD, Pars I. Genesis, p. 47-105.

Cândea, V. (1979). Rațiunea dominantă, Dacia, Cluj-Napoca.

Florescu, I.-F. (2015). In multe chipuri de Scripturi, Editura Universităţii „Alexandru Ioan Cuza”, Iași.

Frâncu, C. (1983-1984). Geneza și evoluția timpurilor verbale supracompuse, în ALIL, XXIX, p. 23-62.

Frâncu, C. (2009). Gramatica limbii române vechi (1521-1780), Editura Demiurg, Iaşi.

Gafton, Al. (2005). După Luther, Editura Universităţii „Alexandru Ioan Cuza”, Iaşi.

Gafton, Al. (2012). De la traducere la norma literară. Contribuția traducerii textului biblic la constituirea vechii norme literare, Editura Universității „Alexandru Ioan Cuza”, Iași.

Gînsac, A.-M. (2013). Les notes marginales sur le texte révisé de l'Ancien Testament traduit par Nicolae Milescu au XVIIe siècle (ms. 45), comunicare suștinută la al XXVII-lea Congres Internaţional de Lingvistică și Filologie Romanică, Nancy, iul. 2013.

Munteanu, E. (2011). Tradiția biblică românească. Coordonate, stadiu al cercetării potențial, în Munteanu, E. et al. (ed.), Receptarea Sfintei Scripturi intre filologie, hermeneutică și traductologie. Lucrările Simpozionului Național «Explorări în tradiția biblică românească şi europeană», Iaşi, 28-29 octombrie 2010, Editura Universității „Alexandru Ioan Cuza”, Iaşi, p. 11-21.

Soare, L. (2015). Învățătură pentru ferirea și doftoria boalelor (1816). Considerații asupra gloselor, în „Diacronia”, nr. 1, 13 ian., art. A9, CrossRef.

Ursu, N.A. (2003). Contribuțiii la istoria culturii românești în secolul al XVII-lea, Editura Cronica, Iași, 2003. 